\title{
PENETAPAN KADAR VITAMIN C PADA KULIT PISANG (Musa paradisiaca) DENGAN METODE SPEKTROFOTOMETRI UV-VISIBLE TAHUN 2018
}

\author{
Asti Pratiwi ${ }^{1}$, Ardita Febrianty Manurung' ${ }^{2}$, Jhoti Sumitra ${ }^{3}$ \\ Institut Kesehatan Medistra Lubuk Pakam \\ e-mail: astipratiwi110@gmail.com
}

DOI : https://doi.org/10.35451/jfm.v2i2.363

\begin{abstract}
:
Vitamin $C$ is a vitamin that is water soluble qnd one vitamin that are needed by the body. To meet the intake of vitamin $C$ needed source of vitamin a derived from fruits, one of which is banana. Part of the banana, which is still rarely used is its skin. Banana peel is very beneficial for health however the situation is only considered as waste that has not been utilized well. This study aims to determine the levels of vitamin $C$ on the skin of the banana (Musa paradisiaca) by the method of spectrofotometry uv-visible wavelength $224,5 \mathrm{~nm}$. This research use experimental with purely research stage comprise sample preparation, qualitative test, making the solution of the parent raw, quantitative test, determination of wavelength of maximum vitamin and creation of calibration surve. Based on the research that has been done obtained the result of the qualitative test to prove the presence of high content of vitamin C contained in banana peels, with the highest level obtained in the skin of the plantain by $0,0253 \mathrm{mg} / \mathrm{ml}$ and the levels of the lowest on a banana peel the wax by $0,0172 \mathrm{ng} / \mathrm{ml}$. Levels of vitamin $C$ on the skin of the banana barangan of $0,0219 \mathrm{mg} / \mathrm{ml}$, sample a banana skin banten by $0,0173 \mathrm{mg} / \mathrm{ml}$, sample a banana peel wax by 0, 0172 $\mathrm{mg} / \mathrm{ml}$ and sample the skin of plantain by $0,0253 \mathrm{mg} / \mathrm{ml}$.
\end{abstract}

Key words : Vitamin C, Skin Banana, spectrofotometry UV-Visible 


\section{PENDAHULUAN}

Vitamin C merupakan salah satu zat gizi yang berperan sebagai antioksidan dan efektif mengatasi radikal bebas yang dapat merusak sel atau jaringan, termasuk melindungi lensa dari kerusakan oksidatif yang ditimbulkan oleh radiasi. Beberapa fungsi lain dari vitamin $C$ yaitu sebagai sintesis kolagen,biosintesis karnitin, $\mathrm{m}$ eningkatkan imunitas dan mencegah timbulnya katarak. Vitamin C tidak dapat dibentuk pada tubuh makhluk

hidup terutama manusia, sehingga diperlukan asupan vitamin $\mathrm{C}$ dari luar. Untuk memenuhi asupan vitamin $C$ dibutuhkan sumber vitamin yang berasal dari buah-buahan, salah satunya adalah pisang (Almatsier, 2016).

\section{Pisang (Musa paradisiaca)}

merupakan tanaman yang mudah hidup di indonesia. Pisang banyak diminati masyarakat khususnya Indonesia dari masyarakat kalangan bawah hingga kalangan atas. Karena mudah didapat dan harganya yang tergolong murah, pisang juga banyak mengandung gizi, sumber vitamin, mineral dan juga karbohidrat. Kandungan di dalam pisang lainnya seperti serat dan vitamin A, B, dan $C$ dapat membantu memperlancar sistem pencernaan, meningkatkan daya tahan tubuh dari radikal bebas, serta menjaga kondisi tetap kenyang dalam waktu lama (Amalia, 2016).

Penggunaan limbah kulit pisang masih sangat sedikit yaitu hanya dimanfaatkan sebagai makanan ternak saja, bahkan masih banyak dijumpai limbah ini hanya dibuang begitu saja. Menurut (Susanti,2006), kulit pisang adalah limbah buangan yang sangat banyak jumlahnya

Pada umumnya kulit pisang belum banyak digunakan secara nyata, hanya saja banyak digunakan sebagai limbah organik atau digunakan untuk makanan ternak seperti kambing, sapi, dan kerbau. Jumlah kulit pisang yang cukup banyak akan memiliki nilai jual yang tinggi apabila bisa digunakan sebagai bahan baku makanan, seperti bahan baku untuk membuat nata dan jelly, serta sebagai bahan baku pada pembuatan kosmetik.

penggunaan limbah kulit pisang dapat dimanfaatkan sebagai bahan baku makanan maupun kosmetik. jumlah kulit pisang cukup banyak, yaitu kira-kira $1 / 3$ dari buah pisang yang belum dikupas. Untuk itu limbah kulit pisang banyak dimanfaatkan sebagai olahan disebabkan karena kandungan gizi di dalam kulit pisang masih cukup lengkap, seperti karbohidrat, lemak, protein, kalsium, fosfor, zat besi, vitamin B, vitamin C dan air.

Kulit pisang yang masak berwarna kuning kaya akan senyawa flavonoid, dan senyawa fenolik. Flavonoid dan senyawa fenolik merupakan senyawa bioaktif yang menunjukkan berbagai ak tivitas yang berguna, seperti antioksida $\mathrm{n}$, antidermatitis, kemopreventif, antikanker, maupun antivirai. Selain itu, kulit pisang mengandung pektin yang dapat dijadikan salah satu obat penurun kadar kolesterol (Sriatun, 2007).

Menurut penelitian yang telah dilakukan oleh Irgiandhini (2016) tentang penetapan kadar vitamin C pada daging dan kulit buah pisang kepok secara spektrofotometri cahaya tampak. Didapatkan hasil kadar ratarata vitamin $\mathrm{C}$ pada kulit buah pisang kepok masak sebesar $54,45 \mathrm{mg} / 100 \mathrm{~g}$ dan 27,26 mg/100g . Hal ini membuktikan adanya kandungan vitamin $C$ pada kulit pisang kepok tersebut sehingga perlu ditetapkan kadar vitamin $\mathrm{C}$ pada jenis kulit pisang 
lainnya, agar dapat meningkatkan penggunaan limbah kulit pisang yang lebih optimal dan bernilai ekonomis dikalangan masyarakat.

Berdasarkan uraian di atas, maka dilakukan penelitian untuk menetapkan kadar vitamin $\mathrm{C}$ pada kulit buah pisang menggunakan metode spektrofotometri Uv-Visible dengan panjang gelombang $264 \mathrm{~nm}$. Penetapan kadar vitamin C pada kulit pisang dengan metode spektrofotometri Uv-Visible dipilih karena memiliki beberapa keuntungan antara lain, pelaksanaannya relatif cepat dan sederhana. sebagai baku pembanding digunakan asam askorbat yang memiliki sifat larut dalam air.

\section{METODE PENELITIAN}

Alat

Alat yang digunakan adalah timbangan analitik, corong, spatel, kertas saring Whatman no 1, labu ukur, gelas ukur, cawan porselin, beaker gelas, tabung reaksi, corong, pipet volum, neraca Analitik, pipet tetes, dan alat Spektrofotometri UV Visibel (UV mini-1240).

\section{Bahan}

Bahan-bahan yang digunakan adalah kulit pisang, asam askorbat, $\mathrm{NaOH} 10$ $\%$, FeSO 5 \%,dan aquabides.

\section{Pengolahan Sampel}

Sampel yang digunakan adalah kulit pisang barangan, kulit pisang banten, kulit pisang lilin dan kulit pisang raja yang dicuci dengan air yang mengalir dan ditiriskan, dipotong kasar, dihaluskan dengan blender dan ditimbang masing-masing sebanyak $100 \mathrm{mg}$.

\section{Uji Kualitatif}

Pada $2 \mathrm{ml}$ larutan sampel ditambahkan 2 tetes $\mathrm{NaOH} \quad 10 \%$ kemudian ditambahkan $2 \mathrm{ml}$ FeSO $45 \%$ amati perubahan warna yang terjadi, reaksi positif ditandai dengan terbentuknya warna kuning $(+)$ mengandung vitamin $C$. ditimbang masing- masing sebanyak $100 \mathrm{mg}$.

\section{Pembuatan Larutan Induk Baku Vitamin C 100 ppm}

Asam askorbat ditimbang sebanyak $50 \mathrm{mg}$ kemudian dimasukkan ke dalam labu ukur $500 \mathrm{ml}$ dan di larutkan dengan aquabidest sampai tanda batas.

\section{Analisis Kuantitatif}

\section{Penentuan Panjang Gelombang} Serapan Maksimum Larutan Vit C

Dipipet $5 \mathrm{ml}$ larutan vitamin $\mathrm{C}$ 100 ppm dan dimasukkan ke dalam labu tentukur $50 \mathrm{ml}$ (konsentrasi 10 ppm) lalu ditambahkan aquabidest sampai tanda batas dan homogenkan. Di ukur serapan maksimum pada panjang gelombang 200- $300 \mathrm{~nm}$ dengan menggunakan blanko aquabidest.

\section{Pembuatan Kurva Kalibrasi}

Larutan vitamin C di pipet 100 ppm dan di masukkan kedalam labu ukur 50 $\mathrm{ml}$ masing - masing sebesar $2 \mathrm{ml}, 3$ $\mathrm{ml}, 4 \mathrm{ml}, 5 \mathrm{ml}$ dan $6 \mathrm{ml}$ ( 4 ppm, 6 ppm, 8 ppm 10 ppm dan 12 ppm). Kemudian ditambahkan aquabidest hingga tanda batas homogenkan dan ukur serapannya pada panjang gelombang maksimum yang di peroleh.

\section{Hasil Dan Pembahasan}

Analisis kualitatif dilakukan sebagai analisis pendahuluan untuk mengetahui ada atau tidaknya vitamin C dalam sampel. Hasil dapat dilihat pada Tabel 1

Tabel 1. Hasil Analisis Kualitatif 


\begin{tabular}{lllll}
\hline No & $\begin{array}{l}\text { Sam } \\
\text { pel }\end{array}$ & $\begin{array}{l}\text { Pere } \\
\text { Aksi }\end{array}$ & $\begin{array}{l}\text { Hasil } \\
\text { Reaksi }\end{array}$ & $\begin{array}{c}\text { Ha } \\
\text { sil }\end{array}$ \\
\hline 1 & Kulit & $\mathrm{NaOH}$ & Kuning & + \\
& Pisan & $10 \%$ & & \\
& Barang & dan & & \\
& an & FeSO4 & & \\
& & $5 \%$ & & \\
2 & Kulit & $\mathrm{NaOH}$ & Kuning & + \\
& Pisang & $10 \%$ & & \\
& Banten & dan & & \\
& & FeSO4 & & \\
& & $5 \%$ & & \\
3 & Kulit & $\mathrm{NaOH}$ & Kuning & + \\
& Pisang & $10 \%$ & Pucat & \\
& Lilin & dan & & \\
& & FeSO4 & & \\
& & $5 \%$ & & \\
4 & Kulit & NaOH & Kuning & + \\
& Pisang & $10 \%$ & Pucat & \\
& Raja & dan & & \\
& & FeSO4 & \\
& & $5 \%$ & \\
\hline
\end{tabular}

Keterangan : $+=$ Mengandung vitamin $C$

\section{Pembahasan}

Pada table 1 di atas menunjukkan bahwa kulit pisang barangan, kulit pisang banten, kulit pisang lilin, dan kulit pisang raja mengandung vitamin $\mathrm{C}$. Sampel di katakana positif mengandung vitamin C jika menghasilkan warna kuning dengan penambahan $\mathrm{NaOH} 10 \%$ dan $\mathrm{FeSO} 4$ 5\%

\section{Analisis Kuantitatif}

\section{Penentuan Kadar Baku Pembanding Vitamin C}

Hasil penetapan kadar asam askorbat p.a (pro analisis) dengan metode spektrofotometri UV-Vis diperoleh kadar rata-rata $224,5 \mathrm{~nm}$. Penetapan kadar dilakukan dengan metode spektrofotometri UV-Vis karena pelaksanaannya relatif cepat dan sederhana dengan menggunakan pelarut aquabidest. Penentuan kadar baku pembanding ini bertujuan untuk meng-nolkan skala absorbansi setiap selesai satu pengukuran dan dihitung nilai absorbansi rata-rata.

\section{Penentuan Panjang gelombang Maksimum}

panjang gelombang digunakan untuk melakukan analisis dimana suatu zat memberikan penyerapan paling tinggi. Hal ini disebabkan apabila pengukuran yang dilakukan pada panjang gelombang yang sama, maka data yang diperoleh semakin akurat atau kesalahan yang muncul akan semakin kecil. Hasil pengukuran yang maksimum dari asam askorbat diperoleh pada pengukuran di panjang gelombang yang memberikan serapan maksimum dengan konsentrasi $2 \mathrm{ml}$ ( 4 ppm).

\section{Kurva Kalibarasi}

Kurva kalibrasi merupakan perb andingan antara konsentrasi dengan nilai absorban. Semakin besar konsentrasinya maka nilai absorbannya akan semakin besar pula. Kurva kalibrasi juga digunakan untuk menentukan kadar asam askorbat dalam sampel, Pada penelitian ini, Penentuan kurva kalibrasi larutan vitamin C dilakukan dengan cara mengukur serapan larutan baku dengan konsentrasi 4 ppm, 6 ppm, 8 ppm, 10 ppm dan 12 ppm yang ditambahkan dengan pelarut aquabidest, kemudian diukur pada panjang gelombang $224,5 \mathrm{~nm}$. Hasil pengukuran kurva kalibrasi dapat dilihat pada Tabel 2 dan Grafik 1 berikut 
Tabel 2. Hasil Pengukuran Absorbansi Vitamin C

\begin{tabular}{ccc}
\hline NO & $\begin{array}{c}\text { Konsentrasi } \\
\text { (PPM) }\end{array}$ & Absorbansi \\
\hline 1 & 0,000 & 0,000 \\
2 & $4 \mathrm{ppm}$ & 0,061 \\
3 & $6 \mathrm{ppm}$ & 0,114 \\
4 & $8 \mathrm{ppm}$ & 0,155 \\
5 & $10 \mathrm{ppm}$ & 0,209 \\
6 & $12 \mathrm{ppm}$ & 0,242 \\
\hline
\end{tabular}

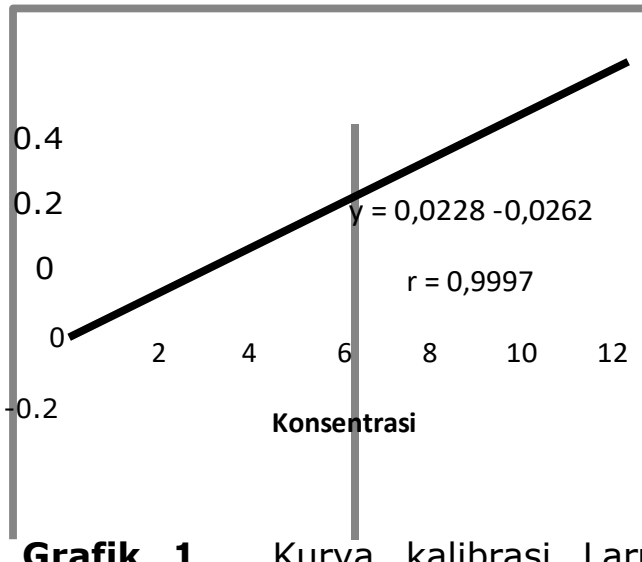

Grafik 1 . Kurva kalibrasi Larutan Standar Vitamin C

Berdasarkan tabel 4 dan grafik 2 kurva standar yang diperoleh menunjukkan bahwa dari hasil pengukuran absorbansi vitamin $\mathrm{C}$ diperoleh hubungan yang linier antara konsentrasi $(X)$ dengan absorbansi $(Y)$ dengan koefisien korelasi $(r)=0,99974$ dan persamaan garis regresi diperoleh $Y=0,0228-0,0262$. Hal tersebut diperoleh dari hasil percobaan yang dilakukan dengan panjang gelombang $224,5 \mathrm{~nm}$ pada konsentrasi $4 \mathrm{ppm}$ (grafik 1 ), yang mana panjang gelombang tersebut digunakan untuk mengukur absorbansi vitamin $\mathrm{C}$ dengan konsentrasi yang lain untuk membuat kurva standar, semakin banyak jumlah zat yang terlarut dalam larutan maka akan mengakibatkan konsentrasi dan absorbansinya semakin besar.
Maka dapat disimpulkan bahwa terdapat hubungan linear yang baik antara konsentrasi dan serapan kurva kalibrasi sesuai dengan literatur. hubungan absorbansi dan panjang gelombang yang didapatkan memenuhi hukum Lambert-Beer, yaitu kurva baku berupa garis lurus (linear). Kemiringan garis ini setara dengan absorbansi. (Gandjar, 2013).

\section{Penetapan Kadar Vitamin C Pada Sampel}

Kadar vitamin $\mathrm{C}$ pada kulit pisang dapat ditentukan dengan cara Spektrofotometri Uv-Visible. Pada metode ini, larutan sampel diletakkan pada sebuah kuvet yang disinari oleh cahaya UV dengan panjang gelombang $224,5 \mathrm{~nm}$. Pemilihan metode ini dilakukan dengan alasan bahwa analisis menggunakan metode ini memiliki hasil yang akurat (Monalisa., dkk. 2013).

Konsentrasi vitamin $C$ dalam sampel ditentukan berdasarkan persamaan garis regresi linier kurva kalibrasi larutan standar vitamin $\mathrm{C}$. karena konsentrasi vitamin $\mathrm{C}$ yang terdapat dalam kulit pisang terlalu besar, maka perlu pengenceran 3 kali, agar berada dalam rentang kurva kalibrasi vitamin C. Pengenceran ini dilakukan agar konsentrasi larutan berkurang atau semakin kecil. Penetapan kadar vitamin C pada kulit pisang dilakukan sebanyak 3 kali pengulangan, dengan maksud untuk mengetahui dan membandingkan hasil dari setiap sampel yang diuji. Hasil dapat dilihat pada tabel 3

Tabel 3 Hasil Analisis Kadar Vitamin C $(\mathrm{mg} / \mathrm{ml})$

\begin{tabular}{ll}
\hline No Sampel & Kadar \\
& Vitamin \\
& $C(\mathrm{mg} / \mathrm{ml})$ \\
\hline
\end{tabular}




$\begin{array}{lll}1 & \text { Kulit Pisang } & 0,0219 \\ & \text { Barangan } & \\ 2 & \text { Kulit Pisang Banten } & 0,0173 \\ 3 & \text { Kulit Pisang Lilin } & 0,0172 \\ 4 & \text { Kulit Pisang Raja } & 0,0253\end{array}$

Kadar Vitamin C dalam suatu
sampel ditentukan dengan metode spektrofotometri uv visible yang dapat dihitung dengan menggunakan persamaan $y=a x+b$, sehingga berdasarkan perhitungan diperoleh kadar Vitamin C pada sampel kulit pisang barangan adalah sebesar $0,0219 \mathrm{mg} / \mathrm{ml}$, untuk sampel kulit pisang banten adalah sebesar 0,0173 $\mathrm{mg} / \mathrm{ml}$, untuk sampel kulit pisang lilin adalah sebesar $0,0172 \mathrm{mg} / \mathrm{ml}$ dan untuk sampel kulit pisang raja adalah sebesar 0,0253 mg/ml. Berdasarkan hasil pada Tabel 2, kita bisa melihat bahwa ternyata dari keempat sampel tersebut kulit pisang raja memiliki kadar vitamin $\mathrm{C}$ yang lebih tinggi sedangkan pada kulit pisang lilin memiliki kadar vitamin $C$ yang lebih rendah. Hal ini terjadi karena adanya beberapa faktor diantaranya perbedaan waktu panen, iklim, tanah dan perbedaan tempat tumbuh (Ita, dkk. 2011).

\section{SIMPULAN DAN SARAN}

\section{Simpulan}

1. Berdasarkan hasil pemeriksaan kandungan vitamin $\mathrm{C}$ pada kulit pisang yang diuji dengan reaksi kualitatif menunjukkan hasil yang positif ditandai dengan perubahan warna kuning dengan

penambahan larutan $\mathrm{NaOH} 10 \%$ dan FeSO4 5\%.

2. Pemeriksaan secara kuantitatif dengan menggunakan spektrofotometri uv visible dengan panjang gelombang 224,5 nm menunjukkan bahwa kadar vitamin C pada kulit pisang barangan sebesar 0,0219 $\mathrm{mg} / \mathrm{ml}$, untuk sampel kulit pisang banten sebesar $0,0173 \mathrm{mg} / \mathrm{ml}$, untuk sampel kulit pisang lilin sebesar 0,0172dan untuk sampel kulit pisang raja sebesar $0,0253 \mathrm{mg} / \mathrm{ml}$. sehingga dapat disimpulkan bahwa kandungan vitamin $\mathrm{C}$ paling banyak terkandung dalam kulit pisang raja dan kandungan vitamin $\mathrm{C}$ paling sedikit terkandung pada kulit pisang lilin.

\section{Saran}

Diharapkan untuk penelitian selanjut nya agar dapat membuat formulasi sediaan vitamin $C$ dari kulit pisang sebagai sediaan krim wajah.DAFTAR PUSTAKA

\section{Buku:}

Almatsier, Sunita (2016). Prinsip Dasar IImu Gizi. Jakarta: PT. Gramedia Pustaka Utama.

Day, R. A. dan Underwood, A.L. (2002).Analisis Kimia Kuantit atif.Penerjemah: Pujaatmaka, A.H., Ed. V. Jakarta: Erlangga. Hal. 393 (Lycopersicum esculentum Mill). Buletin Anatomi dan Fisiologi, 19 (1).

Gandjar, I. G. dan Rohman, A. (2007). Kimia Farmasi Analisis. Yogyakarta Pustaka Pelajar. Hal. 246.

\section{Jurnal:}

Amalia, S. A. (2016). Pengaruh Sumber Nutrisi Acetobacter aceti dan Varietas Kulit Pisang Terhadap Karakteristik Cuka Kulit Pisang. Skripsi. Bandung: 
Fakultas Teknik Pangan. Universitas Pasundan.

Irgiandhini. (2016). Penetapan Kadar Vitamin C Pada Daging dan Kulit Buah Pisang Kepok (Musa Balbasiana BB.) Secara Spektrofotonetri cahaya Tampak. Jurnal Farmasi. Tahun 2016.

Ita, S.R., Endah,D. H.,\& Sri, D. (2011). Pengaruh perlakuan konsentrasi kalsium klorida (Ca $\mathrm{Cl}$ ) dan lama penyimpanan terhadap kadar asam askorbat buah tomat

Kurniawan, J. C. dan Yudhistira, A. 2013. Analisis Fitokimia dan Uji Aktivitas Antioksidan dari Kulit Buah Pisang Goroho (Musa acuminate L.). Jurnal Ilmiah Farmasi. Pharmacon. 2: 23022493.

Monalisa, dkk. (2013). Clinical Aspects Flour Albus of Female and Treatment. IJDV. 1(1): 19-22.

Sriatun. (2007). Identifikasi dan Uji Aktivitas Antioksidan Senyawa Kimia Dari Ekstrak Metanol Kulit Buah Pisang (Musa paradisiaca Linn.). 7 (1), 83-87

Stiani, S. N. (2016). Skrining Fitokimia dan Pembuatan Krim Ekstrak Kulit Pisang Ambon (Musa paradisiaca L) Untuk Luka Bakar. Jurnal Farmasi Vol 3 NO. 1. Tahun 2016.

Susanti, Lina. 2006. Perbedaan Penggunaan Jenis Kulit Pisang Terhadap Kualitas Nata Dengan Membandingkan Kulit Pisang Raja Nangka, Ambon Kuning Dan Kepok Putih Sebagai Bahan
Baku. Tugas Akhir. Semarang: UNNES.

\section{Article Online}

Deekshika B, Praveena Lakshmi B, Hemanth Singuluri, MK Sukumaran (2015) Estimation of ascorbic acid content in fruits $\&$ vegetables from Hyderabad, India - A theoretical assessment of Vitamin C activity. Int J Curr Microbiol App Sci 4(1): 9699.

Elgailani IEH, Gad-Elkareem MAM, Noh EAA, Adam OEA, AlghamdiI AMA (2017) Comparison of two methods for determination of vitamin $C$ in some fruits. American Journal of Chemistry 2(1): 17 